\title{
Russell's
}

\section{THE MAGISTRATE}

\author{
A PRACTICAL HANDBOOK FOR MAGISTRATES \\ AND JUSTICES OF THE PEACE
}

\author{
Second Edition by \\ G. R. OSBORN, Colonial Administrative Service (Ret.); \\ formerly Resident, Ogoja Province, Eastern Nigeria
}

Primarily designed for the use of members of the Colonial Administrative Service, the first edition of this book not surprisingly found favour also with magistrates and J.P.s in the United Kingdom. The changes made for this second edition have therefore been undertaken with a view to making the book even more useful to magistrates generally, as well as in the light of changing conditions in the Commonwealth.

In preparing this new edition of Russell, the editor's aim has therefore been to widen its scope and appeal without in any way detracting from its character. Thus, the general framework of the book has been retained but new matter has been added, certain chapters have been re-written and a short chapter on Land Disputes is now included. Material which had become out of date or which had become too limited in its area of application, has been discarded. As a result of these changes, the book now comprises a collection of practical suggestions not to be found elsewhere, enunciating fundamental principles which are applicable to any magistrate, anywhere and at any time.

Further details may be obtained from:-

\section{BUTTERWORTH \& CO. (AFRICA) LTD. 33/35 BEACH GROVE, DURBAN, SOUTH AFRICA or \\ 88 KINGSWAY, LONDON W.C.2}




\section{The}

\section{House of Butterworth}

We have been producing books since the days of Henry VII and, in the course of our long history, we have published books on all sorts of subjects. Today, however, we specialise in law, medicine and science, and our publications are known the world over.

If you happen to be in London at any time, why not visit our Showroom in Bell Yard, just beside the Law Courts in the Strand? There, the whole range of Butterworth publications is open to your inspection, and the staff will be happy to discuss the books with you and to give you any information or assistance you may require. If you cannot spare the time to call in person, a letter to 88 Kingsway will bring a prompt response to your enquiries. Leaflets about individual books, as well as catalogues giving full details of all our publications will be sent on request-you have only to let us know the the particular subject which interests you. We shall be glad to be of service.

\section{BUTTERWORTHS \\ 88 KINGSWAY, LONDON, W.C.2}

Showroom: 11-12 Bell Yard, Temple Bar, W.C.2 